\title{
Testing and evaluating real driving emissions with PEMS
}

Testing of real driving emissions (RDE) with portable emission measuring system (PEMS) in an appropriate road circuit became an obligatory element of new type approval of passenger cars since September 2017.

In several projects the Laboratory for Exhaust Emissions Control (AFHB) of the Berne University of Applied Sciences (BFH) performed comparisons on passenger cars with different PEMS's on chassis dynamometer and on road, considering the quality and the correlations of results. Particle number measuring systems (PN PEMS) were also included in the tests.

The present paper informs about influences of E85 on RDE on two flex-fuel-vehicles, discusses some aspects of different ways of evaluation with different programs, shows comparison of different types of PN PEMS and represents the effects of simulation of slope on the chassis dynamometer.

Key words: RDE evaluation, RDE with Ethanol, PN PEMS, simulation of slope and normality of RDE results.

\section{Introduction}

Measurement of Real Driving Emissions (RDE) becomes since this year (2017) an element of legal homologation procedure for passenger cars WLTP (Worldwide Harmonized Light-Duty Vehicles Test Procedure) [1-3]. This new procedure will enforce for new cars (introduced to the market since this year), that there will be no discrepancy between the emissions and fuel consumption values obtained in the homologation tests and in real application $[4,5]$.

Unlike previous vehicle emission tests, para-meters such as engine load and vehicle speed are no longer defined by a fixed pattern, but are largely determined by the traffic situation, driver behavior and the course of the route during the RDE test. [6-8].

There are new requirements and challenges for all market participants: the industry has to adapt the R\&D processes of engines, [9-11]; the measuring technics, including PN PEMS are continuously improved and developed, [12, 13] and the official testing laboratories and organisations perform intense research activities in order to increase the knowledge, the experience and to adapt the testing capacities to the new requirements, [4, 5, 7, 8, 14].

In this interesting dynamic situation of progress AFHB performs several test $\&$ research projects, or working packages. Some of the recent results are presented in this paper.

Several countries have objectives to substitute a part of the energy of traffic by ethanol as the renewable energy source and some manufactures introduced the FFV (FlexFuel Vehicles) variants and published extensive information about their R\&D and performances: GM/Saab [15, 16]; Toyota [17]; VW [18]. The RDE with two FFV's and especially with E85 were investigated in the present work.

\section{Test installation}

\subsection{Chassis dynamometer}

Parts of the tests were performed on the 4WD-chassis dynamometer of AFHB (Laboratory for Exhaust Emission Control of the Bern University of Applied Sciences, Biel, $\mathrm{CH}$ ).
The stationary system for regulated exhaust gas emissions is considered as reference.

This equipment fulfils the requirements of the Swiss and European exhaust gas legislation.

- regulated gaseous components:

exhaust gas measuring system Horiba MEXA-7200

$\mathrm{CO}, \mathrm{CO}_{2} \ldots$ infrared analysers (IR)

$\mathrm{HC}_{\mathrm{FID}}$...flame ionization detector for total hydrocarbons

$\mathrm{CH}_{4 \mathrm{FID}}$...flame ionization detector with catalyst for only $\mathrm{CH}_{4}$

$\mathrm{NO} / \mathrm{NO}_{\mathrm{x}} \ldots$ chemiluminescence analyzer (CLA)

The dilution ratio DF in the CVS-dilution tunnel is variable and can be controlled by means of the $\mathrm{CO}_{2}$-analysis .

The measurements of summary particle counts in the size range 23-1000 $\mathrm{nm}$ were performed with the CPC TSI 3790 (according to PMP).

For the exhaust gas sampling and conditioning a ViPR system (ViPR...volatile particle remover) from Matter Aerosol was used. This system contains:

- Primary dilution - MD19 tunable rotating disk diluter (Matter Eng. MD19-2E)

- Secondary dilution - dilution of the primary diluted and thermally conditioned sample gas on the outlet of evaporative tube.

- Thermoconditioner (TC) - sample heating at $300^{\circ} \mathrm{C}$.

\subsection{GAS PEMS and PN PEMS}

An information about the used Horiba Gas PEMS and about the gas measuring installation of the chassis dynamometer is given in Table 1.

As PN PEMS for Real Driving Emissions two systems were used and compared:

- NanoMet3 from TESTO (NM3). This analyzer works on diffusion charging (DC) principle, has an integrated sample conditioning system, as described above for chassis dynamometer and it indicates the solid particle number concentration and geometric mean diameter in the size range $10-700 \mathrm{~nm}$. 
- Horiba OBS-ONE PN measurement system (OBS-PN). This analyzer works on the condensation particles counter (CPC) principle, has an integrated sample conditioning system (double dilution and catalytic stripper ViPR, $350^{\circ} \mathrm{C}$ ) and it indicates the summary PN concentrations in the size range 23 to approximately $1000 \mathrm{~nm}$.

Both systems present several advantages like compactness, robustness, fast on-line response and both are recognized for legal testing purposes.

Table 1. Overview of used measuring systems

\begin{tabular}{|c|c|c|}
\hline & $\begin{array}{c}\text { HORIBA } \\
\text { MEXA } 7200\end{array}$ & $\begin{array}{l}\text { HORIBA } \\
\text { OBS ONE }\end{array}$ \\
\hline & $\begin{array}{c}4 \times 4 \text { chassis dyno } \\
\text { CVS }\end{array}$ & $\begin{array}{l}\text { PEMS (1) } \\
\text { wet }\end{array}$ \\
\hline $\mathrm{CO}$ & NDIR & heated NDIR \\
\hline $\mathrm{CO}_{2}$ & NDIR & heated NDIR \\
\hline $\mathrm{NO}_{\mathrm{x}}$ & CLD & CLD \\
\hline NO & CLD & CLD \\
\hline $\mathrm{NO}_{2}$ & calculated & calculated \\
\hline $\mathrm{O}_{2}$ & - & - \\
\hline $\mathrm{HC}$ & FID & - \\
\hline $\mathrm{PN}$ & not measured & - \\
\hline OBD logger & - & yes \\
\hline GPS logger & - & yes \\
\hline ambient $(\mathrm{p}, \mathrm{T}, \mathrm{H})$ & yes & yes \\
\hline EFM & - & pitot tube \\
\hline
\end{tabular}

OBS - one $\mathrm{H}_{2} \mathrm{O}$ monitored to compensate the $\mathrm{H}_{2} \mathrm{O}$ interference on $\mathrm{CO}$ and $\mathrm{CO}_{2}$ sample cell heated to $60^{\circ} \mathrm{C}$

\section{Test procedures}

\subsection{Driving cycles on chassis dynamometer}

The vehicles were tested on a chassis dynamometer in the dynamic driving cycle WLTC, Fig. 1,

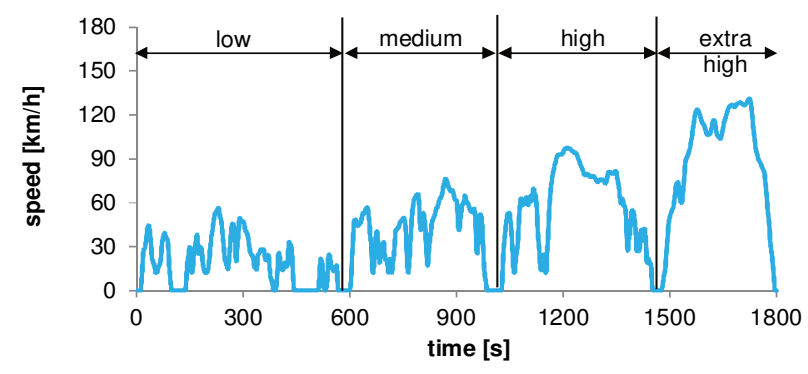

Fig. 1. WLTC driving cycle

For the research about ,slope" a part of real world cycle (like in Fig. 2) was reproduced on the chasssis dynamometer.

For the research with different fuels important objective was to always keep the same procedure of changing the fuel quality. The fuel change was performed at the day preceding the tests. The fuel tank was emptied and filled with the new fuel. Than the vehicle was pushed on the chassis dynamometer, cold-started and driven in one WLTC as condi- tioning. Than the vehicle stayed on the chassis dyno until the next test-day.

The braking resistances were set according to legal prescriptions; they were not increased i.e. responded to the horizontal road.

\subsection{On road testing}

In order to reach the validity according to the actual requirements several road tests were performed. Finally, the used valid road circuit was always the same with approximately $1.5 \mathrm{~h}$ duration and parts of urban, rural and highway roads. Figure 2 represents an example of a road trip from the PN PEMS test program.
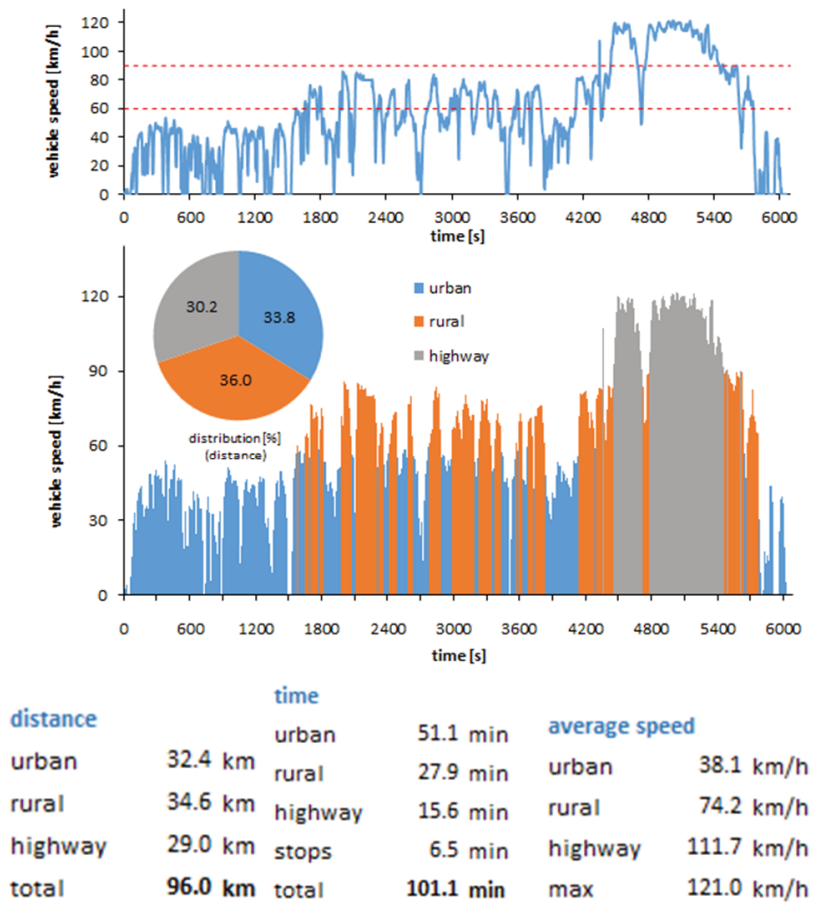

Fig. 2. AFHB, road trip for RDE

\subsection{Test vehicles and fuels}

The tests were performed with two Euro 5 flex fuel vehicles: Volvo V60 (GDI) and Audi A4 TFSI (GDI).

Both vehicles were equipped with PEMS and tested onroad with E0 \& E85. Fig. 3 shows the vehicles in laboratory and Table 2 gives the most important data.

Table 2. Data of tested vehicles

\begin{tabular}{|l|c|c|}
\hline Vehicles & $\begin{array}{c}\text { Volvo V60 T4F } \\
\text { FFV gasoline (V1) }\end{array}$ & $\begin{array}{c}\text { Audi A4 2.0 TFSI FFV } \\
\text { gasoline (V2) }\end{array}$ \\
\hline $\begin{array}{l}\text { Number and } \\
\text { arrangement of } \\
\text { cylinder }\end{array}$ & 4 in line & 4 in line \\
\hline Displacement cm ${ }^{3}$ & 1596 & 1984 \\
\hline Power kW & $132 @ 5700 \mathrm{rpm}$ & $132 @ 4000 \mathrm{rpm}$ \\
\hline Torque Nm & 240 @ 1600 rpm & $320 @ 1500 \mathrm{rpm}$ \\
\hline Injection type & Direct injection (DI) & Direct injection (DI) \\
\hline Curb weight kg & 1554 & 1570 \\
\hline $\begin{array}{l}\text { Gross vehicle } \\
\text { weight kg }\end{array}$ & 2110 & 2065 \\
\hline Drive wheel & Front-wheel drive & Front-wheel drive \\
\hline Gearbox & a6 & m6 \\
\hline First registration & 2012 & 2010 \\
\hline Exhaust & Euro 5a & Euro 5 \\
\hline
\end{tabular}



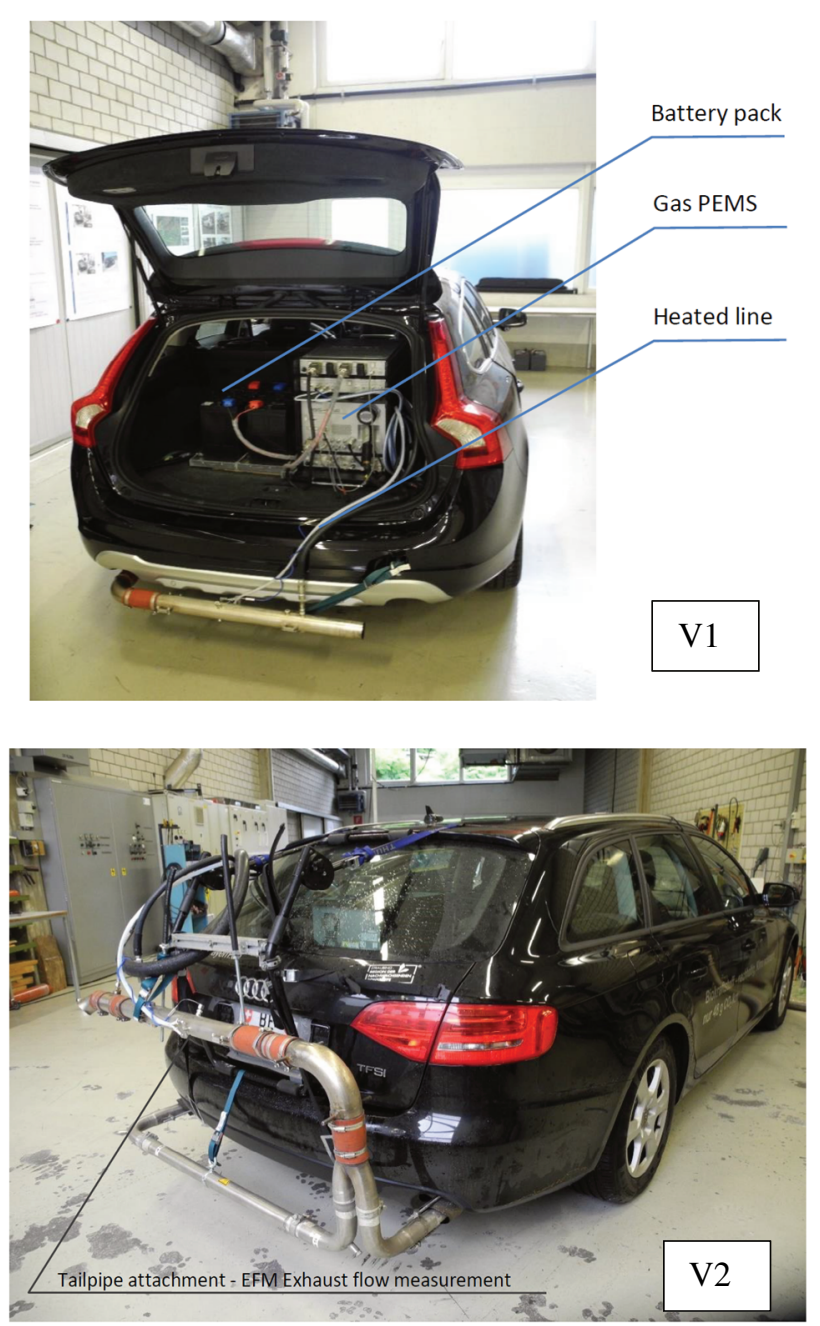

Fig. 3. Tested vehicles (FFV) equipped with PEMS

\subsection{Fuels}

The gasoline used was from the Swiss market, RON 95, according to SN EN228. For the tests a charge of fuel was purchased to keep always the unchanged chemistry.

As a further variants of fuels E10 and E85 were used. These are respectively blends with: $90 \% \mathrm{v}$ gasoline and $10 \% \mathrm{v}$ Ethanol, or with $15 \% \mathrm{v}$ gasoline and $85 \% \mathrm{v}$ Ethanol. The blend fuels were prepared on the basis of E85 purchased on the Swiss market.

Table 3 summarizes the most important parameters of the fuels.

Table 3. Parameters of used fuels

\begin{tabular}{|c|c|c|c|c|c|}
\hline & & Gasoline & $\begin{array}{l}\text { Ethanol } \\
\mathrm{C}_{2} \mathrm{H}_{5} \mathrm{OH}\end{array}$ & E10 & E85 \\
\hline Density $15^{\circ} \mathrm{C}$ & {$\left[\mathrm{g} / \mathrm{cm}^{3}\right]$} & 0.737 & \begin{tabular}{|l|}
0.789 \\
\end{tabular} & 0.742 & 0.781 \\
\hline $\begin{array}{l}\text { Stoichiometric } \\
\text { air/fuel ratio }\end{array}$ & {$[-]$} & 14.6 & 9.0 & 14.0 & 9.8 \\
\hline Lower calorific value & {$[\mathrm{MJ} / \mathrm{kg}]$} & 43.0 & 26.8 & 41.3 & 28.9 \\
\hline Boiling point & {$\left[{ }^{\circ} \mathrm{C}\right]$} & $30-200$ & 78.5 & & \\
\hline Research octane nbr. & {$[-]$} & 95 & 110 & & \\
\hline $\begin{array}{l}\text { Latent heat of evapora- } \\
\text { tion }\end{array}$ & {$[\mathrm{kJ} / \mathrm{kg}]$} & 420 & 900 & & \\
\hline Oxygen content & {$[\% \mathrm{~m}]$} & $<5$ & 34.8 & & \\
\hline
\end{tabular}

\section{Results and discussions}

\subsection{Ethanol blend fuels}

Figure 4 represents the comparisons of average emission values from the operation with gasoline, E10 and E85 in WLTC warm. These results are averages of 2 cycles. The warm-up procedure was always by means of a preliminary cold started WLTC.

The particle counts emissions are generally significantly reduced with Exx (more than 1 order of magnitude).

$\mathrm{CO}$-emissions are clearly reduced with increasing Exxcontent. For $\mathrm{NO}_{\mathrm{x}}$ no regular tendencies with E10 \& E85 are visible. Nevertheless, this is strongly dependent on the electronic control of this FFV and the indicated differences of few [ppm] can also be an effect of emitting dispersion.
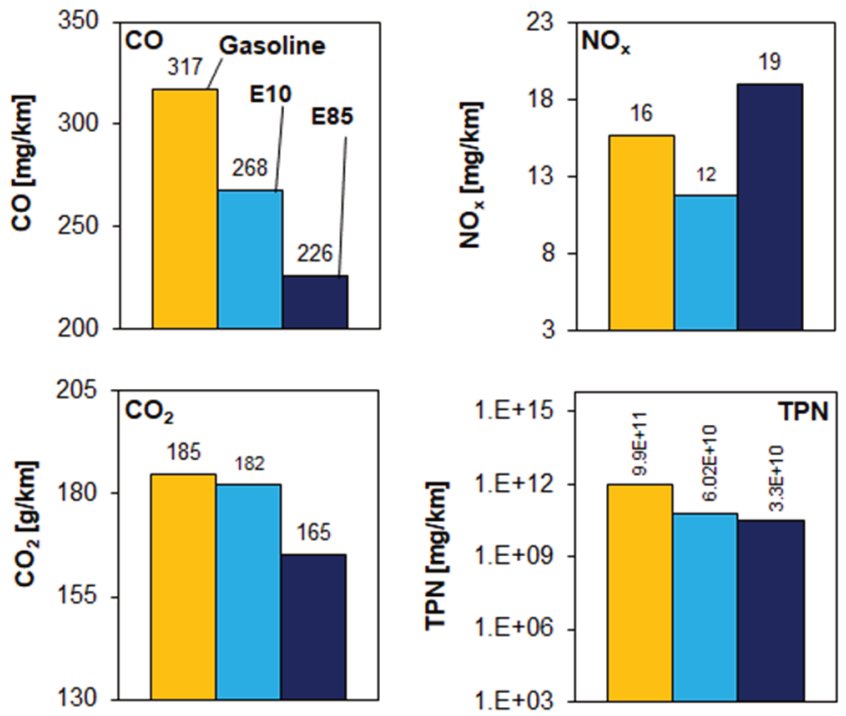

Fig. 4. Average emissions in WLTC warm, with gasoline E10 \& E85 V1: Volvo V60 T4F, 3WC

With each vehicle three RDE tests were performed with E0 and E85. Figures 5, 6, 7 and 8 show the cumulated results of $\mathrm{NO}_{x}, \mathrm{PN}, \mathrm{CO}_{2}$ and $\mathrm{CO}$. The tendencies are similar as in WLTC:

- E85 instead of E0 reduces significantly $\mathrm{NO}_{\mathrm{x}}$-emission; there is a certain dispersion of results, but this tendency is clearer than in WLTC and it is similar for both vehicles,

- PN is strongly reduced with E85 for both vehicles, which confirms the previous experiences on chassis dynamometer with vehicle V1,

E85: $\mathrm{CO}_{2}$ is only slightly reduced with $\mathrm{V} 1$ and more clearly with $\mathrm{V} 2$,

E85: $\mathrm{CO}$ is not reduced with V1 but clearly reduced with V2 - it can be remarked that the acceleration events, very often in the last high-speed part of the cycle, can significantly contribute to the increase of cumulated emission. 

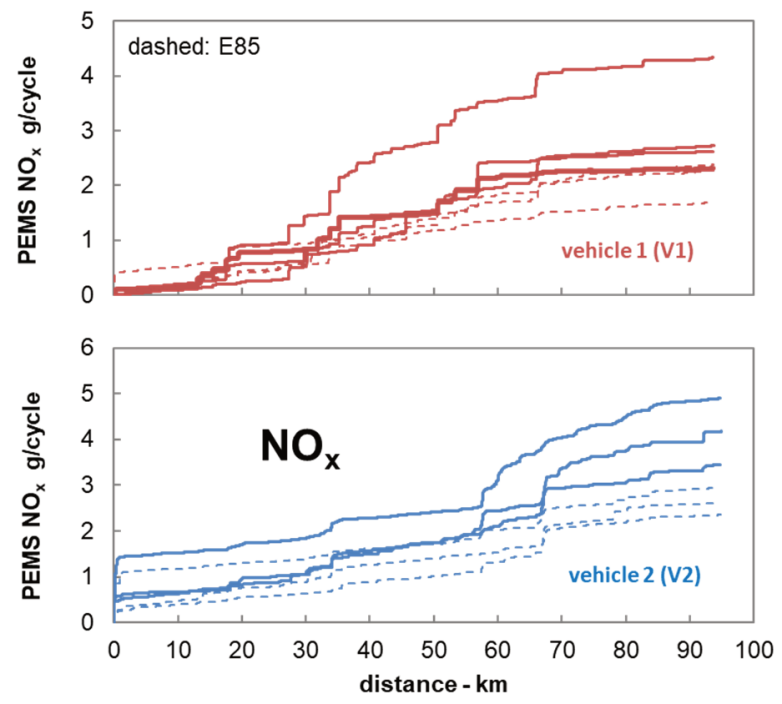

Fig. 5. $\mathrm{NO}_{\mathrm{x}}$ - Emissions during RDE with E0 and E85; Volvo V60 Flexfuel (V1); Audi A4 Flexfuel (V2)
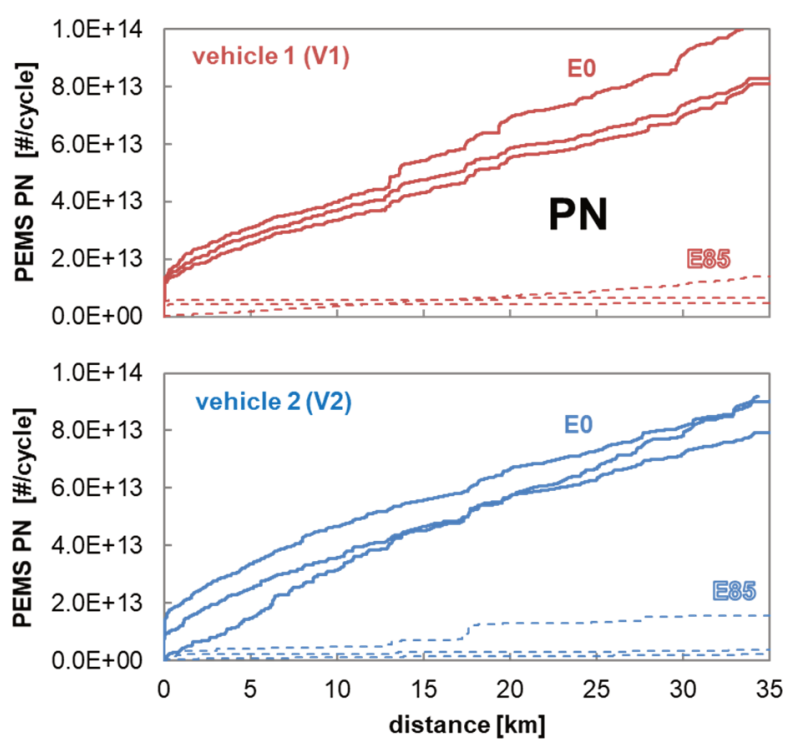

Fig. 6. PN - Emissions during RDE urban part with E0 and E85; Volvo (V1); Audi (V2)

\subsection{Evaluations with EMROAD}

Research of data evaluation was performed with the objective to indicate the influences of different evaluation ways on the results and their relationships.

All this research was performed for both vehicles, but only with the data from gasoline operation.

Figure 9 shows an example of comparisons of results $\mathrm{NO}_{\mathrm{x}} \& \mathrm{CO}$ in one of three RDE-attempts with both vehicles. The results are evaluated with EMROAD MAWmethod (moving averaging windows) and with integration (integral average values). The cold start results are considered, or excluded (as cold start \& warm-up are considered, either the period from engine start to reach $70^{\circ} \mathrm{C}$ coolant temperature, or a time period in maximum $5 \mathrm{~min}$ ).

The integral values (INT) indicate higher emissions $\left(\mathrm{NO}_{\mathrm{x}} \& \mathrm{CO}\right)$ with cold start, than without cold start; this for both vehicles in the entire cycle and in the urban part. This is a usual very well-known result.
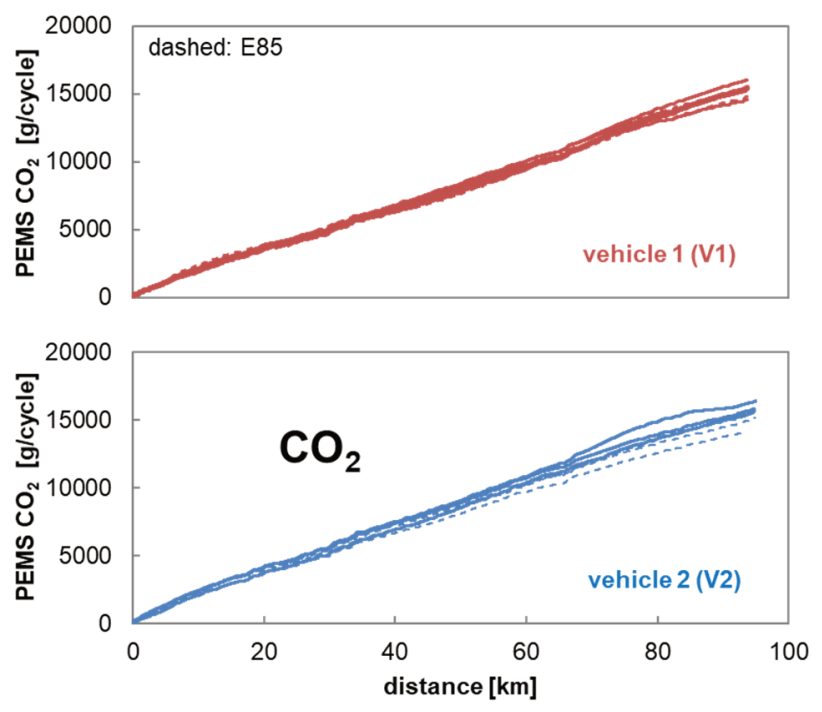

Fig. 7. $\mathrm{CO}_{2}-$ Emissions during RDE with E0 and E85; Volvo (V1); Audi (V2)
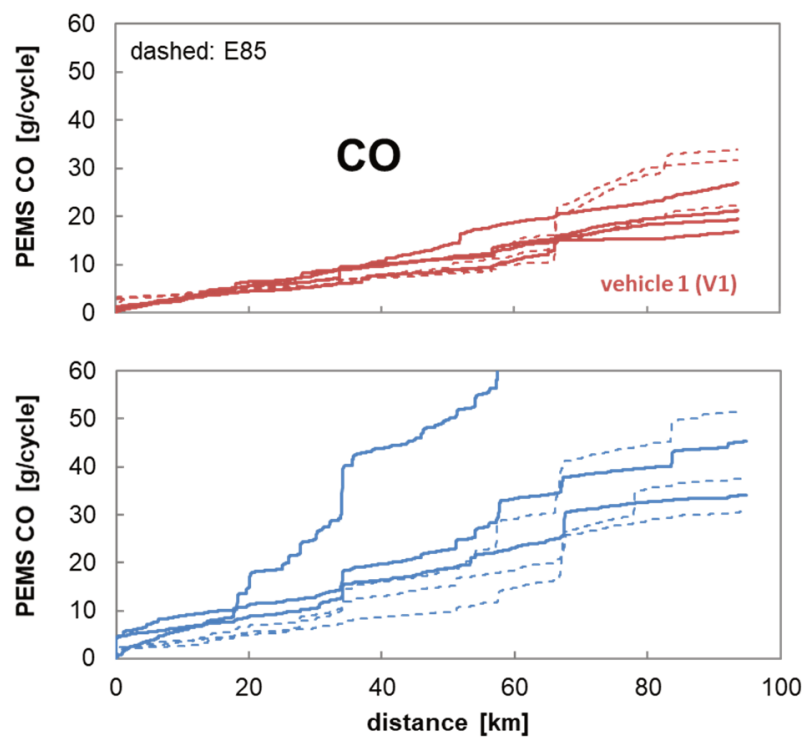

Fig. 8. CO - Emissions during RDE with E0 and E85; Volvo (V1); Audi (V2)

The MAW-method in contrary indicates much smaller differences "with/without cold start" for vehicle V2 and for vehicle V1 even lower $\mathrm{CO}$ - and $\mathrm{NO}_{\mathrm{x}}$-values with cold start. The main reason for that is in the weighing and validation of the windows (MAW). Additionally, it must be remarked that the absolute values of the $\mathrm{CO}-$ and $\mathrm{NO}_{\mathrm{x}}$-emissions are very low and the differences "with/without cold start" are insignificant.

\subsubsection{Influence of weighing and validation on RDE results}

The characterization of normality and completeness of a RDE trip is graphically represented in Fig. 10.

The "normality" of the windows is concluded by comparing their $\mathrm{CO}_{2}$ distance-specific emissions with a reference curve. The test is complete when the test includes enough normal windows, covering different speed areas (urban, rural, motorway). 

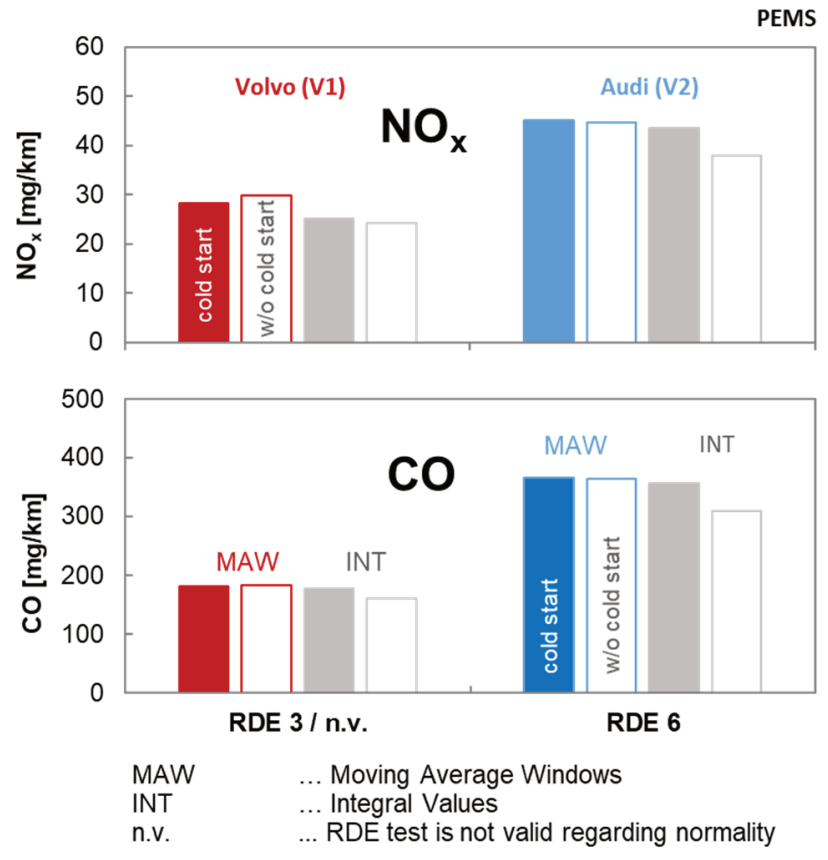

Fig. 9. Influence of cold start on emission results RDE - MAW and integral values

The reference dynamic conditions of the test vehicle are set out from the vehicle $\mathrm{CO}_{2}$ emissions versus average speed measured at type approval (WLTC) and referred to as "vehicle $\mathrm{CO}_{2}$ characteristic curve".

During the MAW evaluation the following steps are performed:

Step 1 Segmentation of the data

Step 2 Calculation of emissions by sub-sets or "windows"

Step 3 Identification of normal windows

Step 4 Verification of test completeness and normality

Step 5 Calculation of emissions using the normal windows.

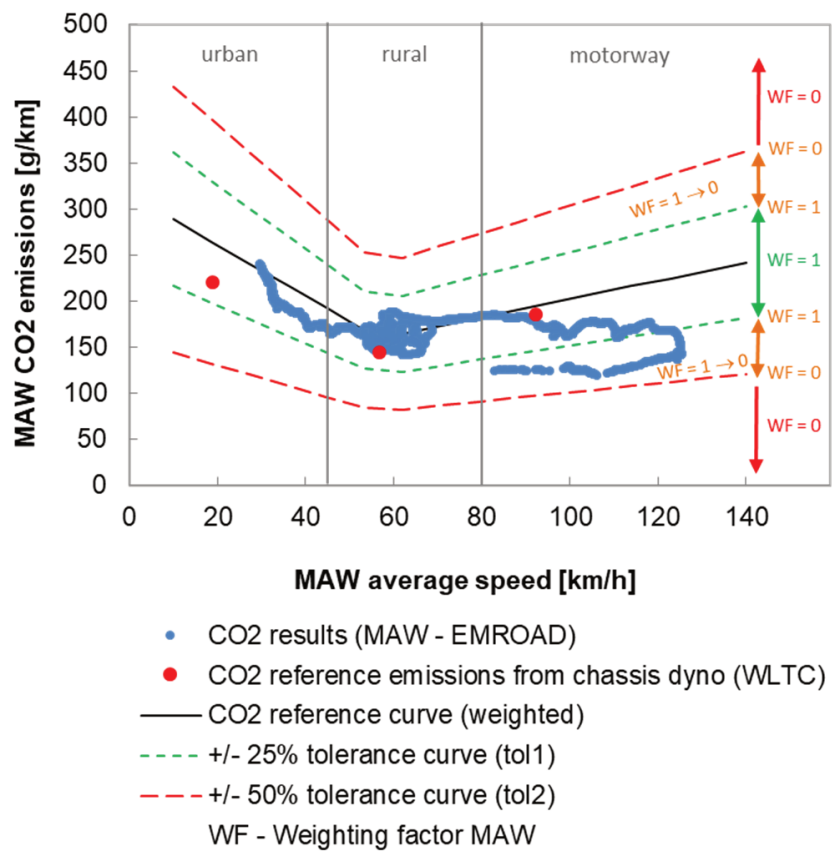

Fig. 10. Characterization of the normality and completeness of a RDE trip
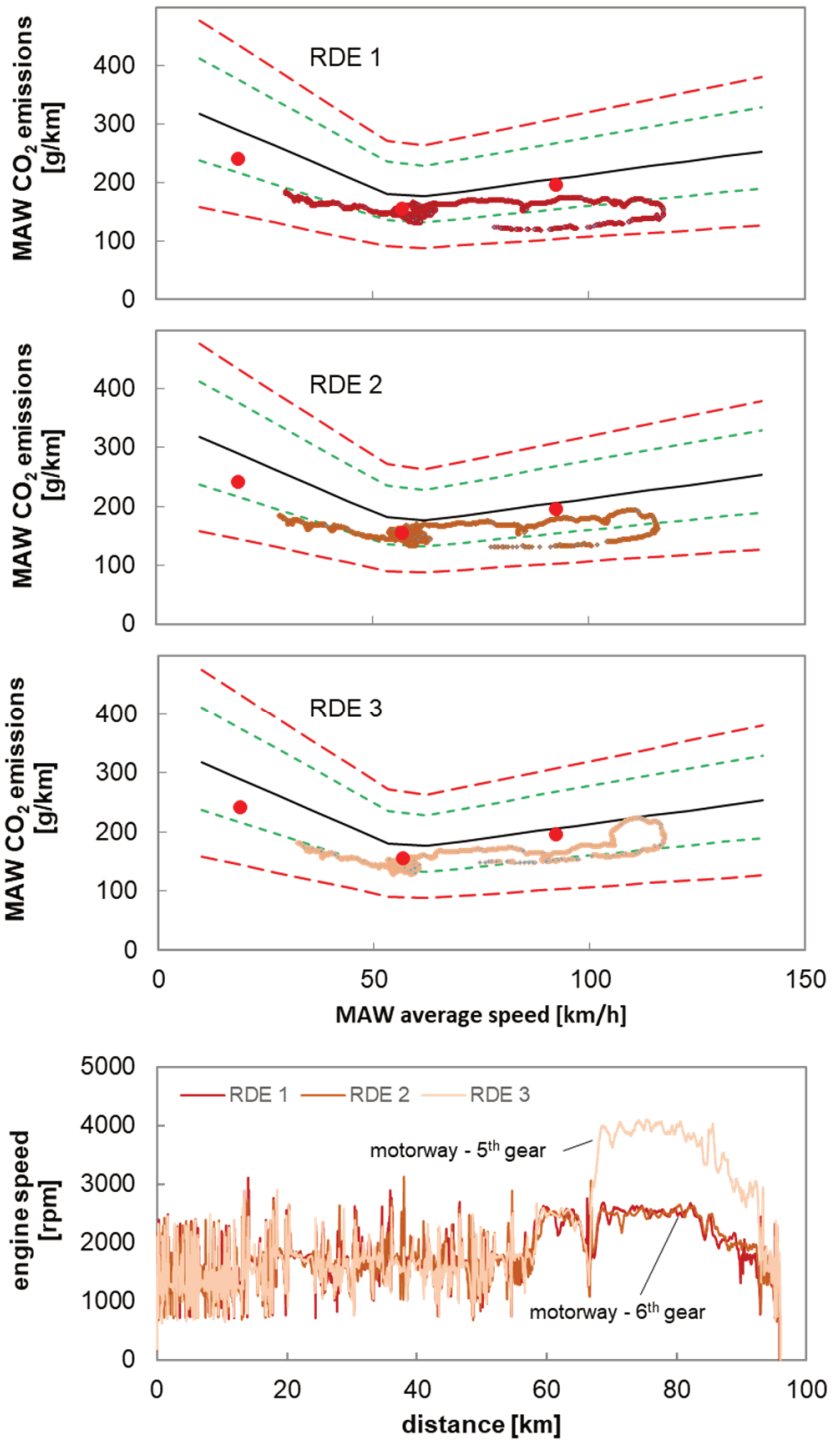

Fig. 11. RDE normality results and vehicle engine speed; Volvo (V1)

The following data are not considered for the calculation of the $\mathrm{CO}_{2}$ mass, the emissions and the distance of the averaging windows:

- the periodic verification of the instruments and/or after

- the zero drift verifications

- the cold start emissions previously excluded are inclu-

- ded in evaluation since September 2017

- vehicle ground speed $<1 \mathrm{~km} / \mathrm{h}$

- any section of the test during which the combustion

- engine is switched off.

In Fig. 11 such $\mathrm{CO}_{2}$ characteristic curves are represented for two of three evaluated trips of vehicle V1. The trips and their dynamic conditions are not entirely normal, since the characteristic curves are exceeding the primary tolerance of $\pm 25 \%$ (of the average WLTC- $\mathrm{CO}_{2}$-values).

The operation of this vehicle $\mathrm{V} 1$ in the urban part (at lowest speeds) is not dynamic enough and the program sets for these windows weighting factors $\mathrm{WF}<1$. At the highest speeds, there are also windows passing over the primary tolerance, because of not sufficient engine load. (The maximum speed on Swiss highway is limited to $120 \mathrm{~km} / \mathrm{h}$ and 
the last part of the highway in the RDE circuit is going downhill).

In the $3^{\text {rd }}$ trip, "RDE3": in the highway part of cycle the automatic gear was limited to select only the 5th speed. This increased the fuel consumption and the $\mathrm{CO}_{2}$ emission in this part of the cycle and it moved the characteristic curve (MAW $\mathrm{CO}_{2}$ vs. MAW speed) in the primary tolerance domain of $\pm 25 \%$.

Summarizing these examples, it can be remarked that: the normality and weighing of the windows have an influence on the final emission results and the characteristic curve of the trip $\left(\mathrm{CO}_{2}\right.$ vs. speed) is recommended to be inside of the primary tolerance band of $\pm 25 \%$ with $\mathrm{WF}=1$.

\subsection{Comparison EMROAD vs. CLEAR}

Both evaluation methods and programs - EMROAD (MAW) and CLEAR (PB - Power Binning) were used and accepted in the EC-legislation.

The power binning method classifies the instantaneous emissions of the pollutants $\mathrm{m}_{\mathrm{gaz}, \mathrm{i}}(\mathrm{g} / \mathrm{s})$ into several power classes according to the corresponding power at the wheels. The method checks that a sufficient number of events fall within each class. The method applies to the total trip and to the urban part $\left(\mathrm{v}_{\mathrm{i}} \leq 60 \mathrm{~km} / \mathrm{h}\right)$.

The actual wheel power $\mathrm{P}_{\mathrm{w}, \mathrm{i}}$ can be either measured by a torque-meter or calculated from instantaneous $\mathrm{CO}_{2}$ emissions, using the vehicle-specific $\mathrm{CO}_{2}$, lines ("Veline") based on WLTC data ((EU) 2016/646 of 20 April 2016).

The maximum wheel power class is the highest class which includes the $90 \%$ of the rated engine power as declared by the manufacturer.
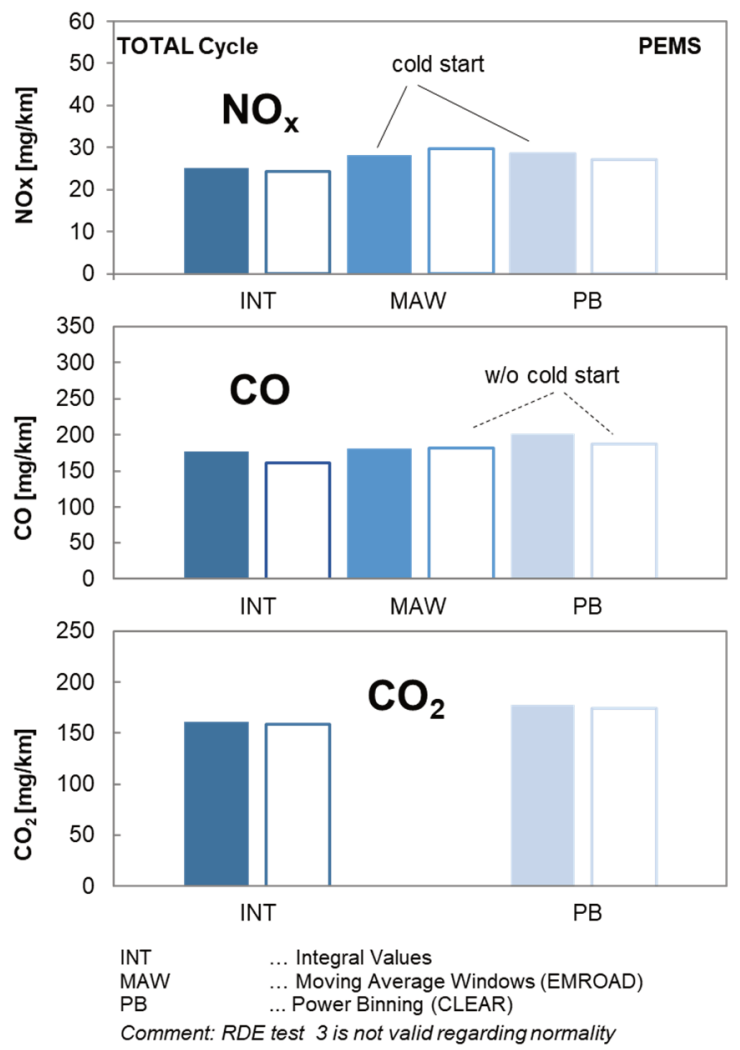

Fig. 12. Comparison of results with and without coldstart RDE - Integral values, MAW and PB; Volvo (V1)
In the present work the results of all evaluation methods (INT/MAW/PB) were compared in $3 \mathrm{RDE}$ tests with and without cold start.

Figure 12 gives an example of this comparison in one of the performed tests. For the same test, there is a dispersion of $\mathrm{NO}_{\mathrm{x}^{-}}$and $\mathrm{CO}$-results in the scattering band of approximately $\pm 7 \%$.

The results with consideration of cold start are with INT \& PB higher, than without cold start. For MAW-method the weighing factors of a non-valid cycle cause the lower emissions with cold start (see previous section).

Fig. 13 shows the distribution of power classes and the $\mathrm{NO}_{\mathrm{x}} / \mathrm{CO}$-emissions per class in the three RDE-trips. It can be remarked that the power class distribution, is very well repetitive, while the emissions (here especially in the test "RDE2") can scatter considerably.

Summarizing: both methods EMROAD and CLEAR have similar but not identical results. In the last amendment to Euro 6 including RDE4 (March 2018) was stated, that the results of both evaluation methodologies were not consistent enough and the CLEAR methodology was deleted.

\subsection{Simulation of slope on chassis dynamometer}

Sometimes in the research activities, the on-road driving cycle is registered and reproduced on the chassis dynamometer. A simulation of slope in WLTC with constant slope $(+/-2 \%)$ in the entire cycle was performed in [19]. An increase of $\mathrm{CO}_{2} \& \mathrm{NO}_{\mathrm{x}}$ with increased slope and no influence of slope on PN were found.

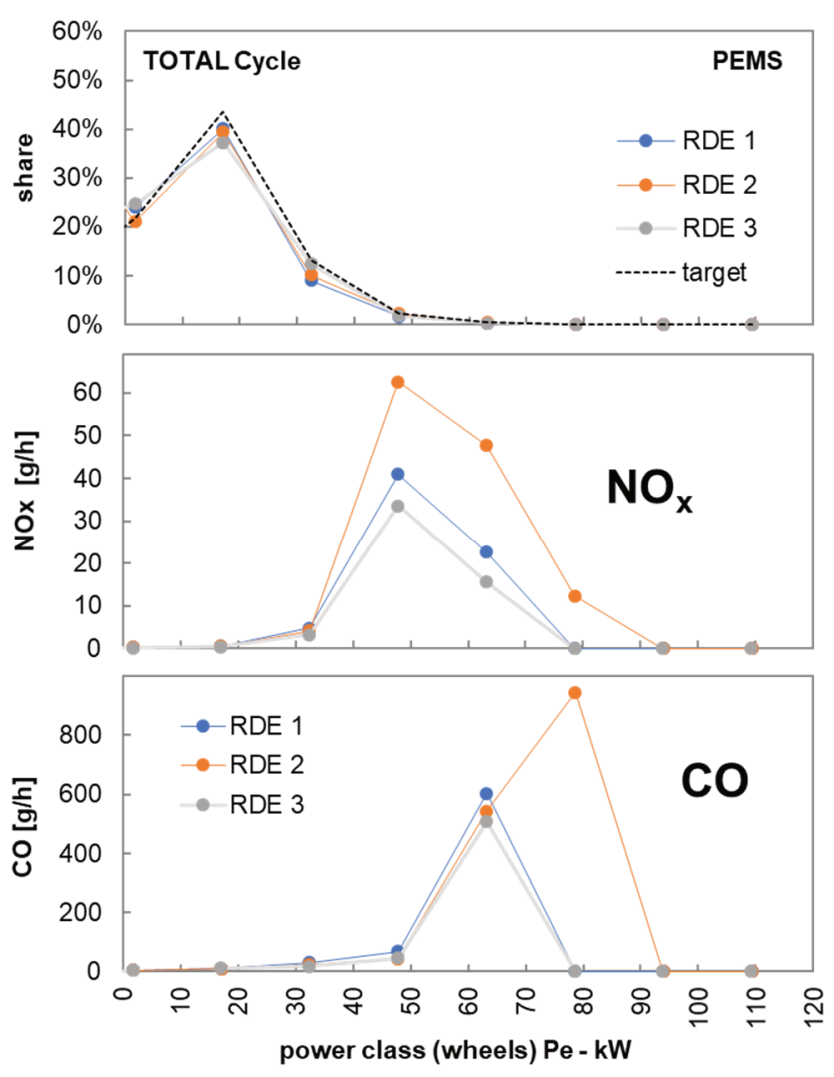

Fig. 13. Power binning results for 3 RDE-Measurements; Volvo (V1) 
In the present work, a part of the RDE-cycle with mostly variable altitude, approximately $8 \mathrm{~min}$. was selected, Fig. 14. The variable slope in this "sub-cycle" was programmed in the chassis dynamometer control system and the tests with this sub-cycle were performed on the vehicle V1. The performance of such a cycle needs a certain preparation and increased attention of the driver.
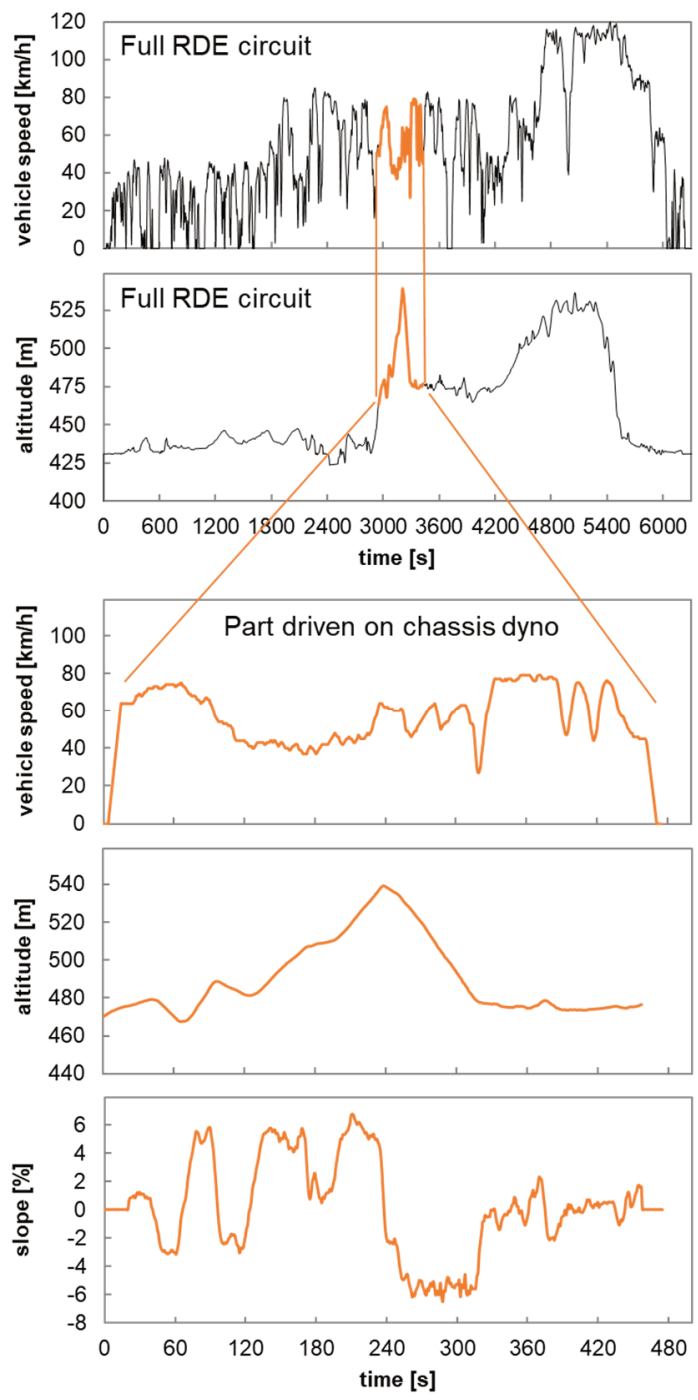

Fig. 14. RDE circuit and part used for chassis dyno measurement; HORIBA OBS One; Volvo (V1)

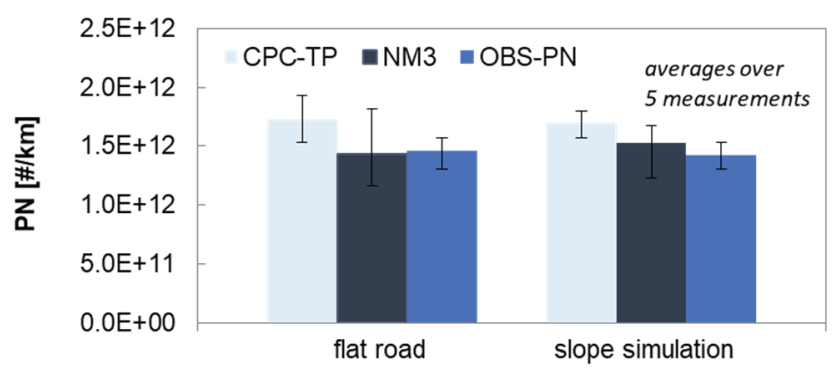

Figure 15 shows the average results with/without slope simulation, obtained with both systems: GasPEMS and bags (CVS). The slope simulation yields higher values of $\mathrm{CO}, \mathrm{CO}_{2} \&$ fuel consumption, the $\mathrm{NO}_{\mathrm{x}}$-values nevertheless are not influenced. Both measuring systems indicate similar absolute values of results.

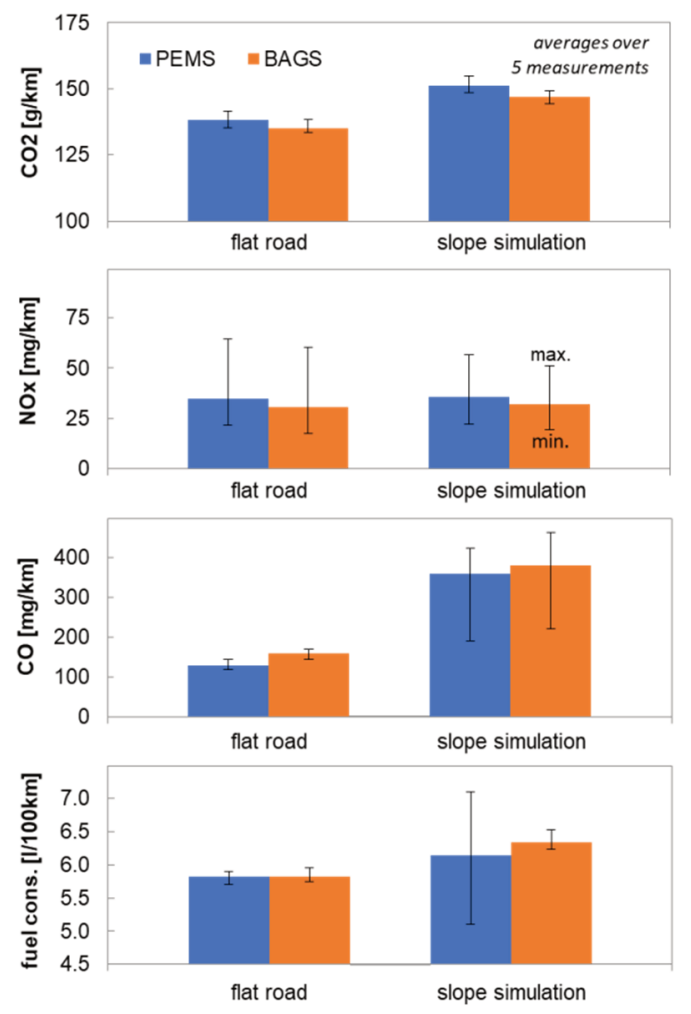

Fig. 15. Influence of real slope simulation on chassis dyno on exhaust emissions; HORIBA OBS One; Volvo (V1)

\subsubsection{Comparisons of PN-PEMS}

During the investigations with simulation of slope following PN measuring systems were included with sampling at tailpipe (TP): CPC, NM3 and OBS-PN (see explanations in section 2).

Figure 16 shows the average results of 5 trials with/without slope simulation. Both PN-PEMS indicate nearly the same PN-values but both systematically slightly lower, than CPC-readings. NM3 shows a higher dispersion of results.

The simulation of slope has no influence on the PN emissions.

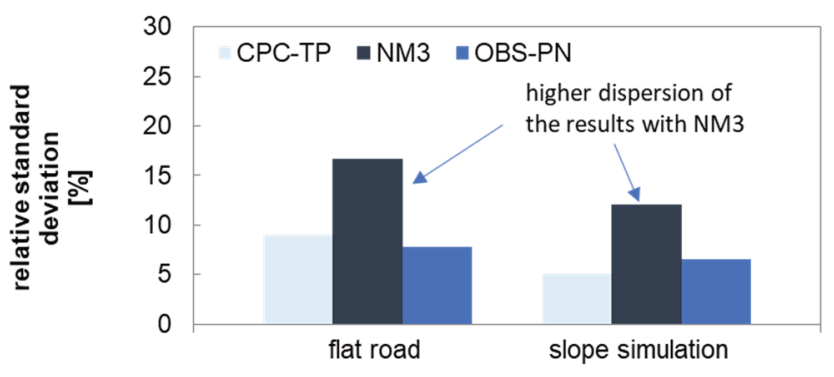

Fig. 16. Simultaneous measurements of PN at tailpipe with ViPR+CPC3790, NM3 and OBS-PN on chassis dyno; HORIBA OBS One; Volvo (V1) 


\section{Conclusions}

Following conclusions can be mentioned:

\subsection{E0 \& E85}

- The use of E85 fuel is advantageous for emission reduction: with $\mathrm{E} 85$ there is reduction of $\mathrm{NO}_{\mathrm{x}}$ and $\mathrm{PN}$ for both investigated vehicles in all driving conditions.

- The volumetric fuel consumption with E85 is generally higher, due to the lower heat value of this fuel.

- Both vehicles attain similar levels of emissions at the end of RDE cycle, while the dispersion of results for each vehicle/fuel variant is much larger than on the chassis dynamometer (in WLTC).

\subsection{Evaluations with EMROAD}

- The normality and weighing of the windows have an influence on the final emission results and the characteristic curve of the trip $\left(\mathrm{CO}_{2}\right.$ vs. speed) is recommended to be inside of the primary tolerance band of $\pm 25 \%$ with $\mathrm{WF}=1$.
- Including the cold start in the evaluation, generally increases the emission results, but in case of non-valid trip and weighing of the windows (MAW) this effect can be weakened or even inversed.

\subsection{EMROAD vs. CLEAR}

Both methods of evaluations of results EMROAD and CLEAR have similar but not identical results. The CLEAR methodology was deleted in the last version of RDE legislation (March 2018).

\subsection{Slope and PN-PEMS}

- The slope has an impact on emissions of $\mathrm{CO}$ and $\mathrm{CO}_{2}$ (fuel consumption) and it should be considered during the reproduction of RDE driving cycles on the chassis dynamometer.

- Nanoparticle emissions are principally independent on slope.

- $\quad$ Both investigated PN PEMS working with different measuring principles (DC vs. CPC) indicate nearly the same PN-values.

\section{Nomenclature}

\begin{tabular}{|c|c|c|c|}
\hline AFHB & Abgasprüfstelle FH Biel, CH & NO & nitrogen monoxide \\
\hline ASTRA & Amt für Strassen $(\mathrm{CH})$ & $\mathrm{NO}_{2}$ & nitrogen dioxide \\
\hline BAFU & Bundesamt für Umwelt, (Swiss EPA) & $\mathrm{N}_{2} \mathrm{O}$ & nitrous oxide \\
\hline $\mathrm{CD}$ & chassis dynamometer & $\mathrm{NO}_{\mathrm{x}}$ & nitric oxides \\
\hline CLA & chemiluminescence analyser & n.v. & non-valid \\
\hline CLD & chemiluminescence detector & OBD & on-board diagnostics \\
\hline CLEAR & RDE evaluation program from TUG with PB & OBS-ONE & Horiba Gas PEMS \\
\hline $\mathrm{CPC}$ & condensation particle counter & OBS-PN & Horiba PN PEMS \\
\hline CVS & constant volume sampling & $\mathrm{OP}$ & operating point \\
\hline DAQ & data acquisition & PB & Power Binning \\
\hline $\mathrm{DC}$ & diffusion charging & PEMS & portable emission measuring systems \\
\hline DF & dilution factor & PMP & EC Particle Measuring Program \\
\hline DI & Direct Injection & PN & particle number \\
\hline DiSC & diffusion charge size classifier & PN-PEMS & PEMS with PN measuring device \\
\hline E0 & gasoline (zero Ethanol) & RDE & real driving emissions \\
\hline E85 & $85 \%$ vol. Ethanol & TC & thermoconditioner \\
\hline $\mathrm{EC}$ & European Commission & TFZ & Technologie- und Förderzentrum für Na- \\
\hline ECE & Economic Commission Europe & & chwachsende Rohstoffe, Straubing, D \\
\hline ECU & electronic control unit & $\mathrm{TP}$ & tailpipe \\
\hline EFM & exhaust flowmeter & TUG & Technical University Graz \\
\hline EMROAD & RDE evaluation program from JRC with MAW & TWC & three way catalyst \\
\hline GDI & gasoline direct injection & V1 & vehicle 1 \\
\hline GMD & geometric mean diameter & $\mathrm{V} 2$ & vehicle 2 \\
\hline $\mathrm{HC}$ & unburned hydrocarbons & ViPR & nanoparticle sample preparation with volatile \\
\hline INT & integral average values & & particles remover \\
\hline JRC & Joint Research Centre (EC) & WLTC & worldwide harmonized light duty test cycle \\
\hline LFE & laminar flow element & WLTP & worldwide harmonized light duty test proce- \\
\hline MAW & moving averaging windows & & dure \\
\hline MFS & mass flow sensor & $3 \mathrm{WC}$ & three way catalyst \\
\hline NM3 & NanoMet3 & & \\
\hline
\end{tabular}

\section{Bibliography}

[1] Official Journal of the European Union: Commission regulation (EU) 2016, 427 of 10 March 2016, amending regulation (EC) No 692/2008.

[2] Commission regulation (EC) no 2008, 692 of 18 July 2008 implementing and amending Regulation (EC) No 715/2007 of the European Parliament and of the Council on typeapproval of motor vehicles with respect to emissions from light passenger and commercial vehicles (Euro 5 and Euro 6 ) and on access to vehicle repair and maintenance infor- 
mation. Available at: http://eur-lex.europa.eu/legal-content/ en/ALL/?uri=CELEX:32008R0692.

[3] Draft of the Annex IIIa: Verifying Real Driving Emissions amending Regulation (EC) No 692/2008 as regards emissions from light passenger and commercial vehicles (Euro 6).

[4] HOFACKER, A. Abgasnorm und Wirklichkeit Eine Annäherung. Springer: MTZ-Motortechnische Zeitschrift. 2015, 76(2), 8-13.

[5] VLACHOS, T.G., BONNEL, P., WEISS, M. Die Bewertung des Abgasverhaltens von Fahrzeugen im realen Fahrbetrieb - Eine Herausforderung für die europäische Emissionsgesetzgebung. 36. Internationales Wiener Motorensymposium, 2015.

[6] GERSTENBERG, J., SCHYR, CH., STERZING-OPPEL, S., TRENKLE, D. RDE engineering via engine-in-the-loop test-bench. MTZ worldwide. 2017, 78(6), 16-23.

[7] CZERWINSKI, J., ZIMMERLI, Y., COMTE, P., BÜTLER, TH. Experiences and results with different PEMS. TAP Paper, International Transport and Air Pollution Conference, May $24^{\text {th }}-26^{\text {th }}, 2016$, Lyon, France.

[8] CZERWINSKI, J., ZIMMERLI, Y., COMTE, P. et al. Potentials of the portable emission measuring systems (PN PEMS) to control real driving emissions (RDE). 38. International Vienna Motor Symposium, 27-28 April 2017, VDI Fortschritt-Bericht Reihe 12, 802, 2.

[9] MASCHMEYER, H., BEIDL, C. RDE Homologation Herausforderungen, Lösungen und Chancen. MTZ. 2016, 77 (10), 84-91.

[10] ZELLBECK, H., WALTER, R., STIEGLER, M., ROß, T. RDE - Der reale Fahrbetrieb auf dem hochdynamischen Motorenprüfstand. MTZ. 2015, 76 (2), 42-47.

[11] RÖTTGER, D., PÉREZ-GUZMÀN, E., VIGILD, CH., DE SMET, F. Feature function development for RDE in Diesel engines. MTZ. 2017, 78 (3), 46-51.

Jan Czerwinski, DEng. - Professor in the University of Applied Sciences, Biel-Bienne, Switzerland.

e-mail:Jan.Czerwinski@bfh.ch

Yan Zimmerli, Dipl. Ing. FH - University of Applied Sciences, Biel-Bienne, Switzerland.

e-mail:Yan.Zimmerli@bfh.ch

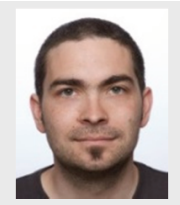

Andreas Hüssy, Bc.Sc. FH - University of Applied Sciences, Biel-Bienne, Switzerland.

e-mail: Andreas.Hhüssy@bfh.ch

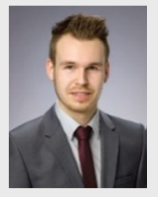

Danilo Engelmann, DEng. - Professor in the University of Applied Sciences, Biel-Bienne, Switzerland.

e-mail: Danilo.Engelmann@bfh.ch
[12] SCHRÖDER, M., BALTES, N., DANZER, J. Impact of RDE legislation on test-bed measurements. MTZ worldwide. 2017, 78 (6), 28-35.

[13] GIECHASKIEL B., RICCOBONO, F., BONNEL, P. Feasibility study on the extension of the real driving emissions (RDE) procedure to particle number (PN). European Commission. Joint Research Centre. ISBN: 978-92-79-51003-8, ISSN: 1831-9424, DOI: 10.2790/74218.

[14] ANDERSON, J., MAY, J., FAVRE, C. et al. On-road and chassis dynamometer evaluations of emissions from two Euro 6 Diesel vehicles. SAE Technical Paper 2014-01-2826. 2014.

[15] BERGSTRÖM, K., MELIN, S.-A., JONES, C. The new ECOTEC Turbo BioPower engine from GM powertrain utilizing the power of nature's resources. 28. Internationales Wiener Motoren-Symposium. 2007, 2, 47.

[16] BERGSTRÖM, K., NORDIN, H., KÖNIGSTEIN, A. et al. $\mathrm{ABC}$ - Alcohol based combustion engines - challenges and opportunities. 16. Aachener Kolloquium Fahrzeug- und Motorentechnik 2007, 2, 1031.

[17] KAWAI, T., TSUNOOKA, T., CHIBA, F. et al. Effect of high concentration ethanol on SI engine cold startabillity and emissions. 16. Aachener Kolloquium Fahrzeug- und Motorentechnik 2007, 2, 1075.

[18] HADLER, J., SZENGEL, R., MIDDENDORF, H. et al. Der $1.41118 \mathrm{~kW}$ TSI für E85 Betrieb - die Erweiterung der verbrauchsgünstigen Ottomotorenlinie von Volkswagen. 32. Internationales Wiener Motorensymposium 2011, 1, 263.

[19] CZERWINSKI, J., COMTE, P., ZIMMERLI, Y. et al. Research of emissions with gas PEMS and PN PEMS. TAP Paper, International Transport and Air Pollution Conference, $15^{\text {th }}-16^{\text {th }}$ November 2017, EMPA, Zürich, Switzerland.

Peter Bonsack, MSc. ME - Federal Office for the Environment FOEN, Bern, Switzerland.

e-mail: Peter.Bonsack@bafu.admin.ch

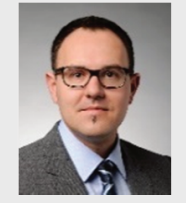

Edgar Remmele, Dr. Dipl. Ing. - Technologie- und Förderzentrum im Kompetenzzentrum für $\mathrm{Na}$ chwachsende Rohstoffe (TFZ).

e-mail: Edgar.Remmele@tfz.bayern.de

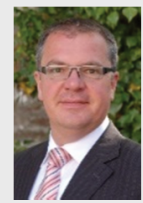

Georg Huber, MSc., Dipl--Ing. (FH) - Technologieund Förderzentrum im Kompetenzzentrum für Nachwachsende Rohstoffe (TFZ).

e-mail: Georg.Huber@tfz.bayern.de

e.muber@tz.bayern.de
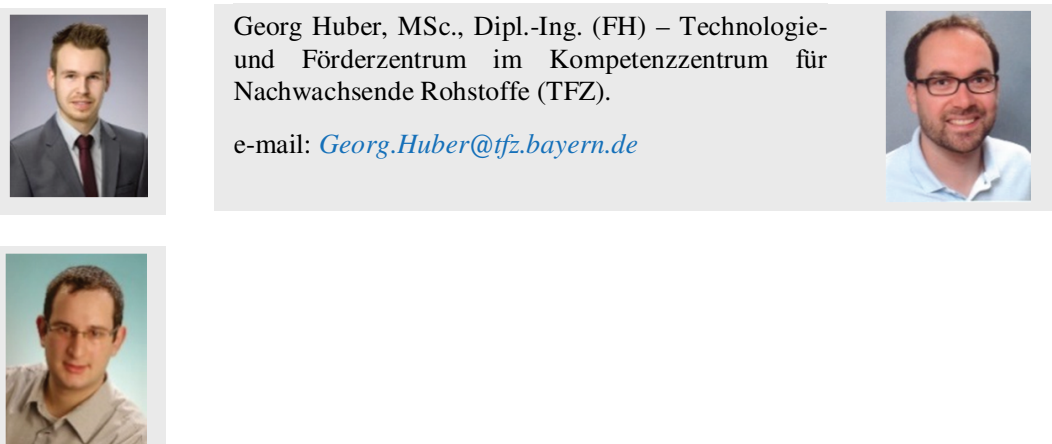